\title{
Physiological and nutritional significance of potassium application under sole and intercropped maize (Zea mays L.)
}

\author{
Aftab Ahmed, ${ }_{1}$ Atta Mohi Ud Din, ${ }^{2}$ Samina Aftab, ${ }^{3}$ John Kwame Titriku, ${ }^{1}$ Shoaib Ahmed, ${ }^{1}$ \\ Muhammad Nizamani, ${ }^{4}$ Zameer Hussain Jamali, ${ }^{5}$ Xiao Tei, ${ }^{1}$ Feng Yang, ${ }^{1}$ Wenyu Yang ${ }^{1}$ \\ ${ }^{1}$ College of Agronomy, Sichuan Agricultural University, Chengdu, Sichuan, China; ${ }^{2}$ College of Life \\ Sciences, Sichuan Agricultural University, Ya'an, Sichuan, China; ${ }^{3}$ College of Management, Sichuan \\ Agricultural University, Chengdu, Sichuan, China; ${ }^{4}$ Sindh Agriculture University, Tandojam Sindh, \\ Pakistan; ${ }^{5}$ College of Environmental Science, Sichuan Agricultural University, Chengdu, Sichuan, China
}

\section{Highlights}

- Potassium nutrient management in maize-soybean strip intercropping can increase the resource use efficiency.

- Compared to the $T_{0}$ (no potassium), $T_{2}\left(80 \mathrm{~kg} \mathrm{ha}^{-1}\right.$ on maize) application increases the light interception and leaf area index of maize by $17 \%$ and $38 \%$ respectively.

- Regression analysis reveals a positive relationship between physiological parameters measured at $R_{2}$ and at $R_{6}$ growth stages in maize under maize-soybean strip intercropping.

- High $\mathrm{K}_{2} \mathrm{O}\left(80 \mathrm{~kg} \mathrm{ha}^{-1}\right)$ inputs enhanced the partitioning of biomass production in maize.

- Overall, the optimum $\mathrm{K}_{2} \mathrm{O}$ application increased the maize yield by $16 \%$ under maize-soybean strip intercropping system relative to control.

\begin{abstract}
Correspondence: Wenyu Yang, College of Agronomy, Sichuan Agricultural University, Chengdu 611130, Sichuan, China.

Tel.: +86.028.86290960; +86.028.862909.

E-mail: mssiyangwy@sicau.edu.cn

Key words: Potassium; biomass; partitioning; fertiliser; intercropping.

Acknowledgements and funding: this research was funded by the International S\&T Cooperation Projects of Sichuan Province grant Number (20GJHZ0068), the National Nature Science Foundation (31571615) and the Program on Industrial Technology System of National Soybean (CARS-04-03A). AA's thanks to Professor Wenyu Yang for his useful advice that significantly improved the quality of the manuscript.
\end{abstract}

Contributions: AA, AMUD, SA, contributed equally to this work; AA, SA and XT, conducted the field experiment, collected all data in both study years, and drafted the manuscript; FY and WY conceived the study, secured the funding, and led the project progress; AA, SA, ZHL, and MN performed the statistical analysis; AA and JKT were involved in the data interpretation; AA, SA and JKT made all figures; AA, and FY reviewed and revised this research paper.

Conflict of interests: the authors declare no potential conflict of interests.

Received for publication: 11 September 2020.

Revision received: 7 January 2021.

Accepted for publication: 8 January 2021.

C Copyright: the Author(s), 2021

Licensee PAGEPress, Italy

Italian Journal of Agronomy 2021; 16:1737

doi:10.4081/ija.2021.1737

This article is distributed under the terms of the Creative Commons Attribution Noncommercial License (by-nc 4.0) which permits any noncommercial use, distribution, and reproduction in any medium, provided the original author(s) and source are credited.

\begin{abstract}
Globally, maize is an essential food and fodder crop. Fertilisers, as soil amendments, particularly $\mathrm{K}_{2} \mathrm{O}$, could increase maize yields. A Two-year field research was designed in 20182019 to examine the influence of three-potassium fertiliser applications on maize-soybean strip intercropping and sole-maize yield components. A Randomized complete block design with three replications was used, and one of three $\mathrm{K}_{2} \mathrm{O}$ doses $\left(\mathrm{T}_{0}, 0 ; \mathrm{T}_{1}\right.$, 40:30; $\mathrm{T}_{2}, 80: 60 \mathrm{~kg} \mathrm{ha}^{-1}$ ) was given in each plot. The effects $\mathrm{K}_{2} \mathrm{O}$ treatments on photosynthetic characteristics, photosynthetic active radiation, leaf area index, total biomass accumulation, and seed yield were investigated at $V_{6}, R_{2}, R_{4}$, and $R_{6}$. Compared to $T_{0}$, maize-soybean strip intercropping system and sole-maize results showed $\mathrm{T}_{2}$ maize enhanced the light interception by $14,26,15$, and $17 \%$ at $V_{6}, R_{2}, R_{4}$, and $R_{6}$ respectively. Maize increased the partitioning of biomass to cob and seed by 8 and $10 \%$ at $R_{6}$, respectively in $T_{2}$, relative to $T_{0}$ treatment. $T_{2}$ showed a higher green leaf area than $\mathrm{T}_{0} ; \mathrm{K}_{2} \mathrm{O}$ applications led to an enhancement in leaf area index at $\mathrm{R}_{6}$ by $38 \%$, under $\mathrm{T}_{2}$, and subsequently increased the photosynthetic rate at $\mathrm{R}_{4}$ and $\mathrm{R}_{6}$ by $8 \%$ and $6 \%$ respectively, in both years of the study. These results suggest that we may increase the accumulation of biomass and the yield of the maize seed under maize-soybean strip intercropping system and sole-maize by optimum $\mathrm{K}$ application in maize plants.
\end{abstract}

\section{Introduction}

Sustainable farming improves crop production through the appropriate usage of chemical fertilisers, pesticides, and nonrenewable resources that adversely contribute to climate change (Pretty, 2008). Researchers recently examined the value of designing cultivation systems that are efficient, enhance quality of produce and environmentally sustainable through the reduction of 
pesticide inputs and non-renewable materials (Moonen and Barberi 2008; Clergue et al., 2009; Wezel et al., 2014). Such systems, for example, strip and relay strip intercropping maximise agricultural productivity (Gliessman 1990; Wezel et al., 2014). Inter-cropping, defined as the growing of two or more crops on the same piece of land at the same time, is valuable for ensuring land productivity and sustainability through facilitation and complementary use of resources (Raza et al., 2019a). Cereals are the largest crop family used in intercropping systems and are important for attaining agricultural productivity and land-use advantage (Yang et al., 2017). Multi-cropping cereals with legumes reduce the competitiveness through facilitation mechanisms like nitrogen fixation by legumes, thereby increasing the use of resources like land, light, and water (Duchene et al., 2017; Yang et al., 2014). A narrow-wide-row planting pattern is mostly used in maize and soybean strip intercropping (MSI) in China. This consists of two rows of maize planted $40 \mathrm{~cm}$ apart in the narrow row and two rows of soybeans planted in wide rows, keeping a distance of $40 \mathrm{~cm}$, while distance between maize and soybean rows is maintained at $60 \mathrm{~cm}$. This planting pattern has proven to increase the rate of photosynthesis of maize plants (Liu et al., 2018).

Balanced management of crop nutrients is a great way of improving agricultural production and smallholder farmers' incomes (Amanullah 2016). The amount of fertiliser utilised in agricultural production systems is necessary to ensure and sustain improved nutritional supplies to plants. Potassium $(\mathrm{K})$ is one of the major plant macronutrients along with nitrogen $(\mathrm{N})$ and phosphorus $(\mathrm{P}) . \mathrm{K}$ is utilised in various enzyme activation, synthesis of protein, starch, cellulose and vitamins, abiotic resistance, and biotic susceptibility, enhances the efficacy of $\mathrm{N}$ and $\mathrm{P}$ usage, and productivity and quality of agricultural crops (Epstein and Bloom, 2005). Optimum potassium sulphate $\left(\mathrm{K}_{2} \mathrm{O}\right)$ helps to ensure the maximum crop yield (Dong et al., 2010; Zhang et al., 2011). In order to meet the ever-increasing amount of food supply (Grote et al., 2005), proper K management is necessary to ensure stable food yield and quality and to preserve agricultural production within intensive agricultural systems (Pettigrew, 2008a; Römheld and Kirkby, 2010). Fertilisation with K remains the main source of $\mathrm{K}$ in most cultivation systems. Even though the rates of application of $\mathrm{N}$ and $\mathrm{P}$ fertilisers have annually been increased, the application rate of $\mathrm{K}$ remains inadequate (Darilek et al., 2009; He et al., 2012). Worldwide, agricultural soils are deficient in K (He et al., 2015), notably Africa (Wortmann and Kaizzi, 1998), Asia (Hedlund et al., 2003), and Europe (Bengtsson et al., 2003). Additionally, growers in China have paid more consideration to N, P fertilisation, but not to $\mathrm{K}$. The imbalanced application of fertilisers contributed to a significant decrease in K (Wang et al., 2008; Zhen et al., 2006). Previous studies have revealed that $\mathrm{K}$ fertiliser application has significantly increased wheat, potato, and rice yields in China (Niu et al., 2013; Li et al., 2015; Cong et al., 2016). Thus, giving more attention to $\mathrm{K}$ fertilisation is essential for sustainable increases in crop production.

Therefore, there is the need to understand physiological K processes regarding yield-trait relationships for the development of fertiliser management practices and agricultural policies to ensure the maximum crop yields. Various experiments have been conducted to determine the $\mathrm{K}$ consumption in relation to maize production (Niu et al., 2011; Dan et al., 2012; Xu et al., 2013). The characteristics of the $\mathrm{K}$ accumulation might differ in conventional cropping systems, and therefore, more information on optimum $\mathrm{K}$ application rates for maize is required to improve $\mathrm{K}$ management strategies in MSI systems. Thus, the objectives of this study were to; i) assess the response of potassium application rates on photosynthetic characteristics, light interception of maize in MSI and solemaize (SM); ii) to analyse biomass accumulation, and grain production of maize under MSI and SM as affected by K treatments.

\section{Materials and methods}

\section{Plant material and locality description}

A two years field experiment was conducted from June to October in 2018 and 2019 at the Modern Research Farm of Sichuan Agricultural University, Chongzhou, Chengdu (31 ${ }^{\circ} 46^{\prime} \mathrm{N}$, $119^{\circ} 00^{\prime}$ E, 535 m elevation), Sichuan Province, P.R. China. The study, in particular, did not contain any endangered or threatened animals, and no approvals were required for the designated locality. Both studies were conducted in agreement with Sichuan Agricultural University, China's organisational rules and regulations. In both years of research, semi-compact variety of maize, Zhenghong 505, and soybean, Nandou 25 cultivars were used. These maize and soybean cultivars are the major cultivars used in the southwest of China (Liu et al., 2016).

\section{Climate and soil characteristics}

The research area has tropical climatic conditions. Weather data obtained from a nearby observatory is presented in (Table 1). The physicochemical features of soil at Chongzhou are reported in Table 2.

Table 1. Monthly rainfall $(\mathrm{mm})$, average temperature $\left(\mathrm{T},{ }^{\circ} \mathrm{C}\right)$, and humidity $(\%)$ during the growing seasons 2018 and 2019 , from June to December.

\begin{tabular}{|c|c|c|c|c|c|c|c|}
\hline \multirow[t]{3}{*}{ Month } & \multicolumn{7}{|c|}{ Years } \\
\hline & \multicolumn{4}{|c|}{2018} & \\
\hline & Rainfall & Maximum T & Minimum T & Humidity & Rainfall & Minimum T & Humidity \\
\hline June & 65.53 & 27.10 & 20.42 & 90.07 & 60.45 & 20.35 & 83.93 \\
\hline July & 223.27 & 29.83 & 22.62 & 93.71 & 240.79 & 21.22 & 90.16 \\
\hline August & 134.11 & 32.38 & 22.21 & 84.53 & 460.78 & 21.72 & 83.55 \\
\hline September & 118.62 & 24.69 & 18.52 & 87.35 & 104.90 & 17.75 & 90.70 \\
\hline October & 20.83 & 19.48 & 13.10 & 86.27 & 17.78 & 16.62 & 92.25 \\
\hline November & 15.89 & 17.79 & 10.59 & 75.04 & 16.23 & 10.34 & 78.74 \\
\hline December & 5.12 & 10.72 & 6.22 & 75.76 & 5.24 & 7.75 & 82.07 \\
\hline June-Dec (Mean) & 83.33 & 23.14 & 16.23 & 84.67 & 129.45 & 16.54 & 85.91 \\
\hline
\end{tabular}




\section{Experiment design and details}

A field-experiment was conducted in a randomised complete block design having three replications. In this experiment two planting patterns, MSI, and SM systems and three potassium treatments: $\mathrm{T}_{0}\left(\mathrm{~K}_{2} \mathrm{O}\right.$ : zero $\mathrm{K}_{2} \mathrm{O}$ application); $\mathrm{T}_{1}$ (maize $\mathrm{K}_{2} \mathrm{O}$ : 40; soybean $\mathrm{K}_{2} \mathrm{O}: 30 \mathrm{~kg} \mathrm{ha}^{-1}$ ); $\mathrm{T}_{2}$ (maize $\mathrm{K}_{2} \mathrm{O}: 80$; soybean $\mathrm{K}_{2} \mathrm{O}: 60 \mathrm{~kg} \mathrm{ha}^{-1}$ ) were used based on recommended rates for Southwest China (Wu et al., 2013) (Figure 1). The MSI used a wide narrow-row planted pattern of alternate maize and soybean strips. Each MSI strip had two maize rows and two soybean rows (2:2). Two rows of maize were planted with two rows of soybean, at a row distance of $40 \mathrm{~cm}$, keeping intra row space of $40 \mathrm{~cm}$, while a spacing of $60 \mathrm{~cm}$ was maintained between maize and soybean rows. In SM cropping, 70 $\mathrm{cm}$ spacing was used between and within maize rows, and each plot size was $36 \mathrm{~m}^{2}$ (6 m wide and $6 \mathrm{~m}$ long). Both crops seeds were over-planted with hand planter at a seed rate of $32 \mathrm{~kg} \mathrm{ha}^{-1}$ and $40 \mathrm{~kg} \mathrm{ha}^{-1}$ of maize and soybean respectively. The seedlings were later thinned to a population of six and ten plants $\mathrm{m}^{-2}$ of maize and soybean respectively in MSI. Similar maize plant population was maintained in SM. Maize and soybean were planted on $10^{\text {th }}$ and $15^{\text {th }}$ June 2018 and 2019, respectively. In MSI and SM, basal $\mathrm{N}$ as urea fertiliser $130 \mathrm{~kg} \mathrm{ha}^{-1}$, P as calcium superphosphate $72 \mathrm{~kg} \mathrm{ha}^{-1}$, and potassium as $\mathrm{K}_{2} \mathrm{O}$ was applied in all plots at the sowing time.
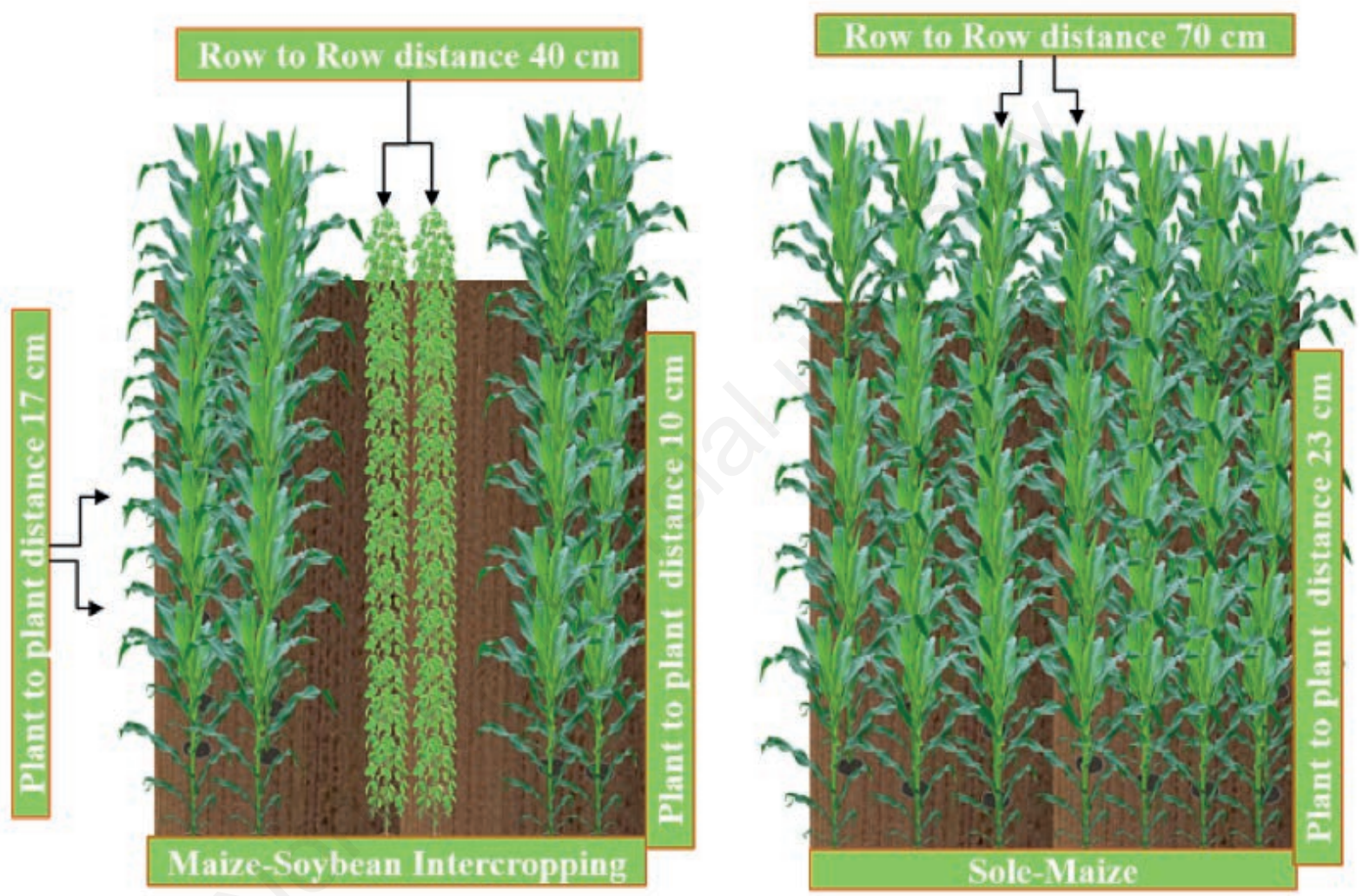

Figure 1. Schematic representations of maize-soybean strip intercropping and sole-maize systems during the season of 2018 and 2019 (Ahmed et al., 2020).

Table 2. Soil characteristics (physical and chemical) before the experiment conducted.

\begin{tabular}{lll}
\hline Parameters & Method & Reference \\
$\begin{array}{l}\text { Soil texture } \\
\text { (Sand } 54 \%, \text { silt 28\%, and clay 18\%) }\end{array}$ & Hydrometer & (Page et al., 1982) \\
$\mathrm{N}_{\text {Total }} 0.90 \mathrm{~g} / \mathrm{kg}$ & Kjeldahl acid digestion & (Olsen and Sommers, 1982) \\
\hline $\mathrm{P}_{\text {Total }} 0.62 \mathrm{~g} / \mathrm{kg}$ & P-Olsen method & (Huoyan et al., 2016) \\
$\mathrm{K}_{\text {Total }} 6.28 \mathrm{~g} / \mathrm{kg}$ & Flame photometer (Jenway, UK) & (Jenkinson, 1968) \\
\hline $\mathrm{N}_{\text {Avalable }} 63.5 \mathrm{mg} / \mathrm{kg}$ & $\begin{array}{l}\text { Automatic discontinuous analyser } \\
\text { (Clever chem200, Germany) }\end{array}$ & (Olsen, 1954) \\
$\mathrm{P}_{\text {Available }} 40.57 \mathrm{mg} / \mathrm{kg}$ & & (Jackson, 1973) \\
\hline $\mathrm{K}_{\text {Available }} 96.36 \mathrm{mg} / \mathrm{kg}$ & & (Homer and Pratt, 1961) \\
Organic matter $30.34 \mathrm{~g} / \mathrm{kg}$ & & (Pietsch and Mabit, 2012) \\
\hline Soil & & \\
\hline
\end{tabular}


The second application of $\mathrm{N}$ as urea $80 \mathrm{~kg} \mathrm{ha}^{-1}$ was applied at the sixth-leaf growth stage of maize. All other agronomic practices followed were based on crop demand and agricultural practices common in the region. Weeds were controlled manually, and pests and diseases were monitored throughout the experimental period. The crop was rain-fed; no irrigation was applied during both years of study. The maize crop was harvested in the last week of August 2018 and 2019, while soybean was harvested at the end of October 2018 and 2019.

\section{Observations}

\section{Light interception}

The photosynthetic active radiation (PAR) assessment in different $\mathrm{K}$ treatments was done to determine light changes in the maize plant environment. To measure the PAR, light sensors (LI191SA) quantum sensors, (LI-COR Inc., Lincoln, NE) were positioned on the horizontal arm of the observation scaffold over the maize canopy and at ground level at four growth stages viz; $V_{6}, R_{2}$, $\mathrm{R}_{4}$, and $\mathrm{R}_{6}$ (sixth leaf, blister, dough, and physiological maturity stages) across all plants grown in MSI and SM. The PAR was observed for each treatment on a clear sunny day three times at various points over the maize canopy from 10 a.m. to 12 a.m. Three technical repeats were taken on average every time.

\section{Chlorophyll content and gas exchange parameters}

Maize chlorophyll content was measured at four growth stages $\left(\mathrm{V}_{6}, \mathrm{R}_{2}, \mathrm{R}_{4}\right.$, and $\mathrm{R}_{6}$ ) using the SPAD-502 Minolta chlorophyll meter from all experimental plots. In each plot, healthy, and representative plants were marked with plastic rope. A portable photosynthesis device LI-6400 (LI-COR Inc.) embedded with an LED leaf chamber was used to assess the gas exchange parameters, including photosynthesis-rate ( $\mathrm{Pn})$, stomatal conductance (Gs), transpiration rate $(\mathrm{Tr})$ and intercellular $\mathrm{CO}_{2}$ concentration $(\mathrm{Ci})$, of maize leaves. To observe the photosynthetic characteristics, completely expanded maize ear leaves were selected and measured at $\mathrm{V}_{6}, \mathrm{R}_{2}, \mathrm{R}_{4}$, and $\mathrm{R}_{6}$ in all plots. Altogether, the observations were recorded on a clear sunny-day from 9 a.m. to 11 a.m. with a carbon dioxide concentration of $400-\mu \mathrm{mol} \mathrm{mol}{ }^{-1}$.

\section{Leaf area index and biomass accumulation}

Maize plants leaf area index (LAI) was calculated for each treatment in the central rows at four growth stages $V_{6}, R_{2}, R_{4}$, and $\mathrm{R}_{6}$. The overall maximum width and length of the leaf were calculated by the help of a ruler, leaf area estimated by multiplying the crop co-efficient factor of maize 0.70 with the leaf length, and width (Rahman et al., 2017). Six consecutive maize plants, excluding border plants, were randomly sampled from each experimental plot at $\mathrm{V}_{6}, \mathrm{R}_{2}, \mathrm{R}_{4}$, and $\mathrm{R}_{6}$, for determining biomass accumulation and its distribution in various plant parts. All samples collected in the same plot were at a minimum of one meter apart from the previous samples. The harvested plants were separated into different parts, such as belowground (roots) and aboveground (leaves, stem, cob, and seed). For analysing the total dry matter accumulation and partitioning, plants were placed at $65^{\circ} \mathrm{C}$ for one hour in an oven to destroy the fresh tissues and later dried at $80^{\circ} \mathrm{C}$ until a constant weight has achieved.

\section{Grain yield and yield attributes}

In this research, to analyse the yield response, at the maturity stage, 24 ears from the central strips of individual treatments were sampled. The harvested ears were dried for six days in the sunshine, threshed and weighed with a scale to determine the grain yield in all plots, and then converted to ton per hectare $\left(\mathrm{t} \mathrm{ha}^{-1}\right)$; seed number per plant $\left(\mathrm{SP}^{-1}\right)$ was also recorded for all collected ears. Three heaps comprising of 1000 seed were selected from bulk seed stock of each treatment and dried at $65^{\circ} \mathrm{C}$ in an oven until a constant weight was attained. The seeds were weighed with an electronic balance and the average weight determined. At physiological maturity, the harvest index (HI) was calculated as a ratio of seed yield $\left(\mathrm{t} \mathrm{ha}^{-1}\right)$ to the total above ground biomass $\left(\mathrm{t} \mathrm{ha}^{-1}\right)$ and denoted in percentage.

\section{Statistical analysis}

Data of each treatment was arranged and organised in Microsoft-Excel; analysis of variance (ANOVA) was done using Statistix software (Statistix version 8.1). Analysis of variance and least significance difference (LSD) test at the $5 \%(\mathrm{P}=0.05)$ level of significance was used to calculate the physiological and nutritional

\section{Maize-2018}

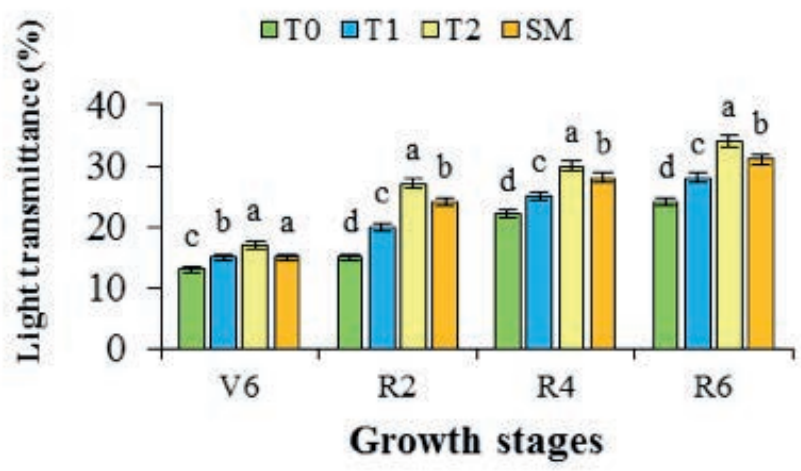

Maize-2019

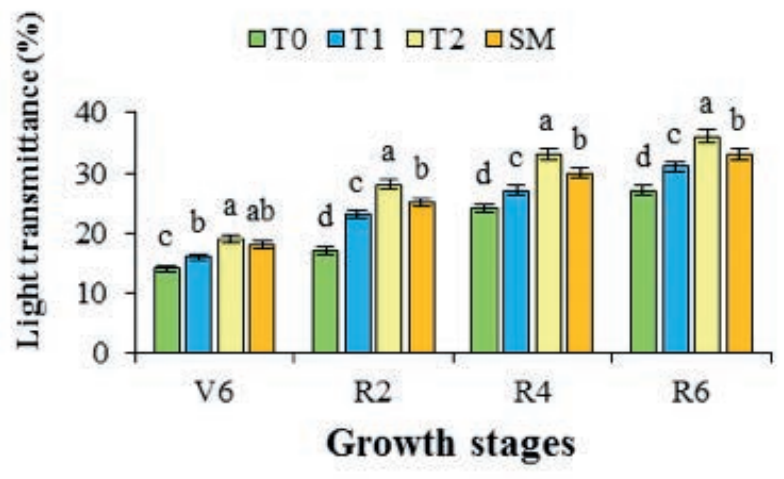

Figure 2. Effect of $\mathrm{K}_{2} \mathrm{O}$ treatments in light transmittance between maize rows for 2018 and 2019, three growth stages of maize $V_{6}$, $R_{2}$, $R_{4}$, and $R_{6}$ (six-leaf, blistering stage, dough stage, and physiological maturity) of maize plants, respectively. $T_{0}$ (no potassium), $T_{1}$ (maize 40 and soybean $30 \mathrm{~K}_{2} \mathrm{O} \mathrm{kg} \mathrm{ha}{ }^{-1}$ ), and $T_{2}$ (maize 80 and soybean $60 \mathrm{~K}_{2} \mathrm{O} \mathrm{kg} \mathrm{ha}{ }^{-1}$ ) represent the treatment, respectively, in maize-soybean intercropping. The SM refers to the sole maize cropping. Means averaged over three replicates. Bars show \pm standard errors $(\mathrm{n}=3$ ). 
significance of potassium application in the sole and intercropped maize. Plots of residuals from ANOVA revealed that the data confirmed the assumptions of the analysis without the requirement of transformation. For the graphical presentation of results, Microsoft Excel-2013 software was used using the standard error $( \pm \mathrm{SE})$. A regression analysis to examine the relationship between potassium treatments and some measured parameters was conducted with Statistix 8.1.

\section{Results}

\section{Effects of potassium concentration on light interception of maize crop}

The results of light interception of intercropped and sole cropped maize collected at $V_{6}, R_{2}, R_{4}$, and $R_{6}$ in response to different $\mathrm{K}$ treatments are shown in (Figure 2). The mean maximum light interception (LI) was observed in $\mathrm{T}_{2}$ while the minimum LI was recorded in $\mathrm{T}_{0}$ at $\mathrm{V}_{6}, \mathrm{R}_{2}, \mathrm{R}_{4}$, and $\mathrm{R}_{6}$, growth stages in both cropping systems. Different $\mathrm{K}_{2} \mathrm{O}$ treatments had significant effects on LI $(\mathrm{P}<0.05)$. Averaged over two years, the maximum LI values of $18,27,31$, and $36 \%$ were observed under treatment $\mathrm{T}_{2}$, and the minimum LI values $13,16,23$, and $25 \%$ were observed under treatment $\mathrm{T}_{0}$ at four growth stages $\left(\mathrm{V}_{6}, \mathrm{R}_{2}, \mathrm{R}_{4}\right.$, and $\left.\mathrm{R}_{6}\right)$ respectively. In addition, on average, relative to control $\left(\mathrm{T}_{0}\right)$, treatment $\mathrm{T}_{2}(80: 60$ $\mathrm{kg} \mathrm{ha}^{-1}$ ) enhanced the light interception by $14,26,15$ and $17 \%$ at $\mathrm{V}_{6}, \mathrm{R}_{2}, \mathrm{R}_{4}$, and $\mathrm{R}_{6}$, respectively, indicating that $\mathrm{K}_{2} \mathrm{O}\left(\mathrm{T}_{2}\right)$ significantly increased the LI within the canopy of maize under MSI and SM.

\section{Effects of potassium concentration on leaf area index}

The effects of various $\mathrm{K}$ treatments on the LAI of maize crops
Maize-2018

$\square \mathrm{T} 0 \square \mathrm{T} 1 \square \mathrm{T} 2 \mathrm{SSM}$

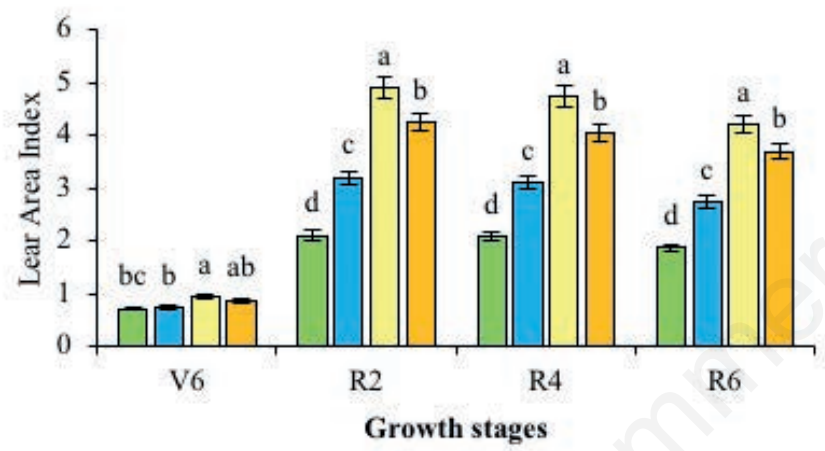

Maize-2019

$\square \mathrm{T} 0 \quad \square \mathrm{T} 1 \square \mathrm{T} 2 \square \mathrm{SM}$

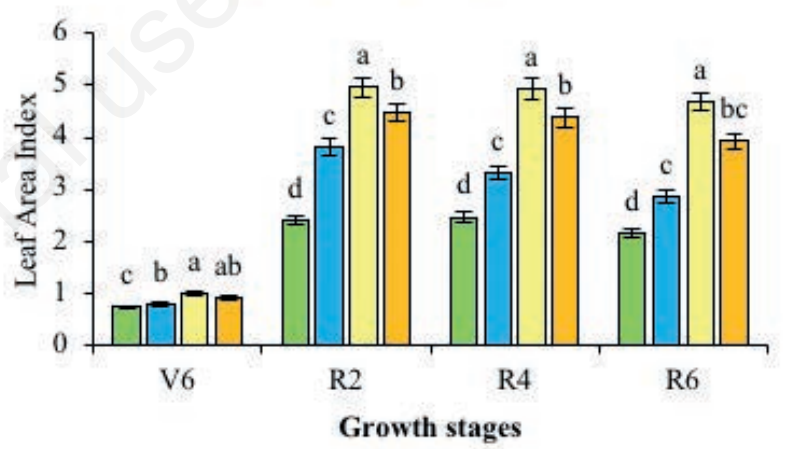

Figure 3. Effects of potassium on leaf area index of maize plant at $V_{6}, R_{2}, R_{4}$, and $R_{6}$ (sixth-leaf, blistering, dough, and physiological maturity) for 2018 and 2019. $T_{0}$ (no potassium), $T_{1}$ (maize 40 and soybean $30 \mathrm{~K}_{2} \mathrm{O} \mathrm{kg} \mathrm{ha}{ }^{-1}$ ) and $\mathrm{T}_{2}$ (maize 80 and soybean $60 \mathrm{~K}_{2} \mathrm{O} \mathrm{kg}$ $\mathrm{ha}^{-1}$ ) represent the treatment, respectively, in maize-soybean intercropping. The SM refers to the sole maize cropping. Error bars indicate \pm standard errors.
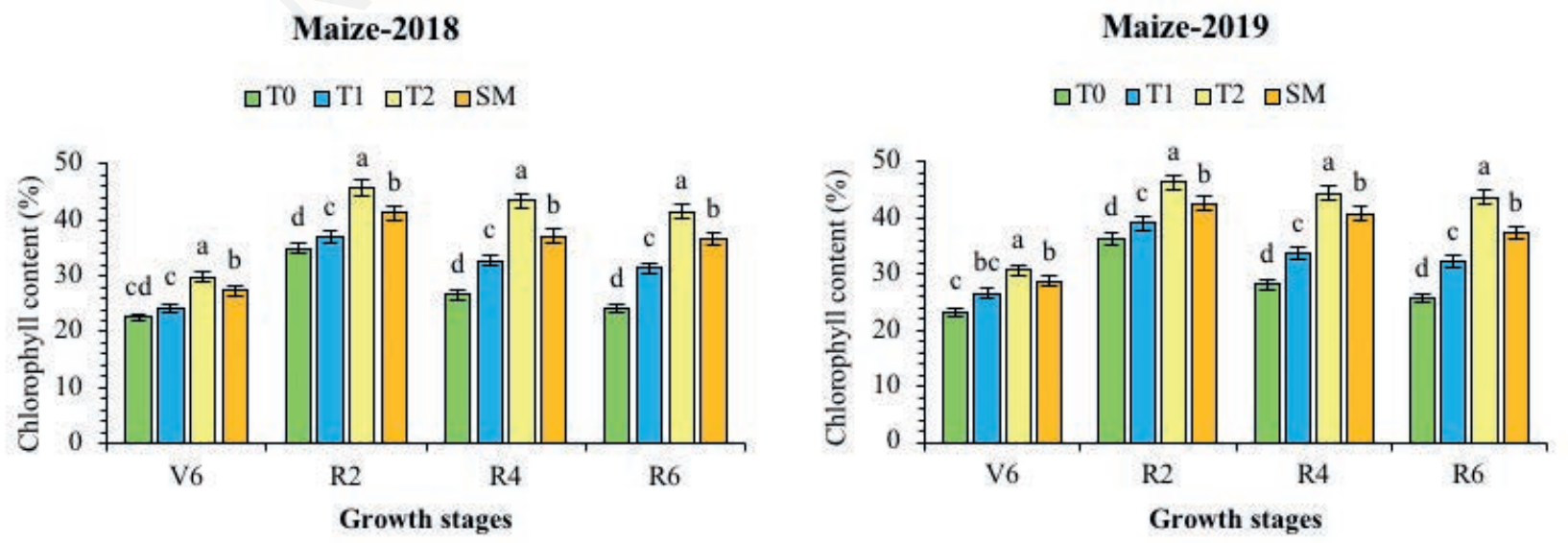

Figure 4. Effects of potassium on chlorophyll contents (\%) of maize plant at four stages $V_{6}, R_{2}, R_{4}$, and $R_{6}$ (six-leaf, blistering, dough, and physiological maturity), for 2018 and 2019. $T_{0}$ (no potassium), $T_{1}$ (maize 40 and soybean $30 \mathrm{~K}_{2} \mathrm{O} \mathrm{kg} \mathrm{ha-1}$,) and $T_{2}$ (maize 80 and soybean $60 \mathrm{~K}_{2} \mathrm{O} \mathrm{kg} \mathrm{ha}{ }^{-1}$ ) represent the treatment, respectively, in maize-soybean intercropping. The SM refers to the sole maize cropping. Error bars indicate \pm standard errors. 
varied significantly $(\mathrm{P}<0.05)$ from $\mathrm{V}_{6}, \mathrm{R}_{2}, \mathrm{R}_{4}$, and $\mathrm{R}_{6}$ stages (Figure 3). In SM, the mean maximum LAI value of 5.77 was calculated at $\mathrm{R}_{2}$ both years of research, whereas in MSI, the mean highest LAI values $0.98,6.2,5.51$, and 3.59 were observed in $T_{2}$ treatments $V_{6}$, $\mathrm{R}_{2}, \mathrm{R}_{4}$, and $\mathrm{R}_{6}$ growth stages respectively in both years. All the $\mathrm{K}_{2} \mathrm{O}$ treatments significantly $(\mathrm{P}<0.05)$ affected the LAI of maize plants. However, the mean average of both years LAI of maize at $\mathrm{T}_{2}$ treatment was significantly increased in $\mathrm{R}_{2}$ by $38 \%$. Finally, the above findings demonstrate the significant association between LAI and $\mathrm{K}$ applications in maize plants. While, the mean maximum LAI of $\mathrm{SM}$ at $\mathrm{T}_{2}$ treatment significantly increased in $\mathrm{R}_{2}$ by $23 \%$.

\section{Effects of potassium concentration on chlorophyll con- tent of maize}

Figure 4 shows the chlorophyll contents of plants in MSI and $\mathrm{SM}$ maize as affected by various $\mathrm{K}_{2} \mathrm{O}$ treatments. At all stages, chlorophyll content of maize plants was significantly $(\mathrm{P}<0.05)$ affected by different $\mathrm{K}_{2} \mathrm{O}$ treatments. Under various $\mathrm{K}_{2} \mathrm{O}$ applications, the mean maximum chlorophyll contents were observed in $\mathrm{T}_{2}, 30.9,43.9$, and 42.6 at four growth stages (sixth-leaf, blistering, dough, and physiological maturity), respectively. Moreover, in both years of experiment, the interactions of $\mathrm{K}_{2} \mathrm{O}$ treatments and the years at all growing stages on chlorophyll contents were found to be non-significant $(\mathrm{P}>0.05)$ (Figure 4). Overall, as compared to $\mathrm{T}_{0} \mathrm{~K}_{2} \mathrm{O}$ treatments, the chlorophyll contents of maize leave increased by 5 and $29 \%$ at $\mathrm{R}_{2}$ in $\mathrm{T}_{1}$ and $\mathrm{T}_{2}$ treatments, respectively, in both years.

\section{Effects of potassium concentration on photosynthetic characteristics of maize}

The photosynthesis characteristics of the maize leaves under MSI and SM were measured to examine improvements in maize photosynthesis in response to different $\mathrm{K}_{2} \mathrm{O}$ treatments (Table 3 ). In both years of research, significant differences $(\mathrm{P}<0.05)$ in $\mathrm{Pn}$, $\mathrm{Gs}$, $\mathrm{Tr}$, and $\mathrm{Ci}$, were noted among the various $\mathrm{K}_{2} \mathrm{O}$ treatments at all measured growth stages of the maize plants. The mean maximum values of $\mathrm{Pn} 23.8,22.3$ and $18.7 \mu \mathrm{mol} \mathrm{CO} \mathrm{Cm}^{-2} \mathrm{~s}^{-1}$, $\operatorname{Tr} 2.80,2.45$ and $1.68 \mathrm{mmol} \mathrm{H}_{2} \mathrm{O} \mathrm{m}^{-2} \mathrm{~s}^{-1}$, Gs $0.21,0.20$ and $0.18 \mathrm{mmol} \mathrm{H}_{2} \mathrm{O} \mathrm{m}^{-}$ ${ }^{2} \mathrm{~s}^{-1}$ and $\mathrm{Ci}$ 99.71, 113.38 and $111.89 \mu \mathrm{mol} \mathrm{CO}_{2} \mathrm{~m}^{-2} \mathrm{~s}^{-1}$ were recorded at $\mathrm{R}_{2}, \mathrm{R}_{4}$, and $\mathrm{R}_{6}$, respectively in $\mathrm{T}_{2}$ treatments in MSI. The mean maximum Pn of 22.76, 20.52, and $17.03 \mu \mathrm{mol} \mathrm{CO}_{2} \mathrm{~m}^{-2}$ $\mathrm{s}^{-1}$ was recorded for $\mathrm{SM}$ at three growth stages $\left(\mathrm{R}_{2}, \mathrm{R}_{4}\right.$, and $\left.\mathrm{R}_{6}\right)$, respectively, in both years. Compared to $\mathrm{T}_{0}, \mathrm{~K}_{2} \mathrm{O}$ treatments of $\mathrm{T}_{2}$ $80: 60 \mathrm{~kg} \mathrm{ha}^{-1}$ significantly increased $(\mathrm{P}<0.05)$ the $\mathrm{Pn}$ of maize leaves by 10,8 , and $6 \%$ at $R_{2}, R_{4}$, and $R_{6}$, respectively in intercropped maize indicating a linkage between $\mathrm{Pn}$ and variations in amounts of potassium applied.

\section{Effects of potassium concentration on an accumulation of total biomass and partitioning}

Figure 5 shows the different $\mathrm{K}$ treatment effects on total biomass accumulation (TBA) at $\mathrm{V}_{6}, \mathrm{R}_{2}$ at $\mathrm{R}_{4}$, and $\mathrm{R}_{6}$, respectively. The mean maximum dry matter accumulation and its distribution were observed at the $\mathrm{R}_{6}$ growth stage of maize in both years of experiment. In this experiment, the mean maximum TBA in MSI was $26,139.9,235.7$ and 258.4 g plant $^{-1}$ in $\mathrm{T}_{2}$ while SM achieved 25.40, 157.6, 222.0, and 234.10 g plant $^{-1}$ at $V_{6}, R_{2}, R_{4}$, and $R_{6}$, respectively. Furthermore, compared to treatment $T_{0}$ treatment, $T_{2}$ $\left(80: 60 \mathrm{~kg} \mathrm{ha}^{-1}\right)$ remarkably enhanced the TBA of maize plants at $\mathrm{R}_{6}$ by $34 \%$ and $33 \%$ in 2018 and 2019 , respectively. During all the development stages $\left(\mathrm{R}_{2}, \mathrm{R}_{4}\right.$, and $\left.\mathrm{R}_{6}\right)$ of maize, we also calculated biomass distribution to different plant parts; the maximum biomass partitioning was noted in the stem at $\mathrm{R}_{2}$ and $\mathrm{R}_{4}$. However, the highest accumulation of biomass was observed in grains, followed by leaves, stem, and cob (Figure 5). The average highest partitioning of biomass in reproductive parts, cob and grain increased from $\mathrm{R}_{2}$ to $\mathrm{R}_{6}$, in both years of study. At $\mathrm{R}_{6}$ in SM TBA in the cob, $38.69 \mathrm{~g}$ plant $^{-1}$, and seed, $105 \mathrm{~g} \mathrm{plant}^{-1}$ was recorded. Interestingly in MSI, the $\mathrm{K}_{2} \mathrm{O}$ processes modified the distribution of biomass in maize, and the maximum biomass accumulated in cob 39.76 and seed $106.15 \mathrm{~g}$ plant $^{-1}$ was observed at $\mathrm{R}_{6}$ in both years in $T_{2}$ treatment.

Table 3. Effects of potassium, on photosynthetic parameters of maize plants at the $R_{2}, R_{4}$, and $R_{6}$ (blistering stage, dough stage, and physiological maturity) for 2018 and 2019.

\begin{tabular}{|c|c|c|c|c|c|c|c|c|c|c|c|c|c|}
\hline \multirow[t]{2}{*}{ Years } & \multirow[t]{2}{*}{ Treatments } & \multicolumn{3}{|c|}{$\begin{array}{l}\text { Photosynthetic } \\
\text { rate }(\mathrm{Pn}) \\
\mu \mathrm{mol} \mathrm{CO} \mathrm{m}^{-2} \mathrm{~s}^{-1}\end{array}$} & \multicolumn{3}{|c|}{$\begin{array}{l}\text { Stomatal conductance } \\
\text { (Gs) } \mathrm{mol} \mathrm{H}_{2} \mathrm{O} \mathrm{m}^{-2} \mathrm{~s}^{-1}\end{array}$} & \multicolumn{3}{|c|}{$\begin{array}{l}\text { Transpiration rate (Tr) } \\
\qquad \mathrm{mmol} \mathrm{H}_{2} \mathrm{O} \mathrm{m}^{-2} \mathrm{~s}^{-1}\end{array}$} & \multicolumn{3}{|c|}{$\begin{array}{l}\text { Intercellular } \mathrm{CO}_{2} \text { concentration } \\
\text { (Ci) } \mu \mathrm{mol} \mathrm{CO} \mathrm{m}^{-2} \mathrm{~s}^{-1}\end{array}$} \\
\hline & & $\mathbf{R}_{2}$ & $\mathbf{R}_{4}$ & $\mathbf{R}_{6}$ & $\mathbf{R}_{2}$ & $\mathbf{R}_{4}$ & $\mathbf{R}_{6}$ & $\mathbf{R}_{\mathbf{2}}$ & $\mathbf{R}_{4}$ & $\mathbf{R}_{6}$ & $\mathbf{R}_{2}$ & $\mathbf{R}_{4}$ & $\mathbf{R}_{6}$ \\
\hline \multirow[t]{9}{*}{2018} & $\mathrm{~T}_{0}$ & $18.28^{d}$ & $16.27^{\mathrm{d}}$ & $16.02^{\mathrm{d}}$ & $0.21^{\mathrm{d}}$ & $0.20^{\mathrm{d}}$ & $0.19^{\mathrm{d}}$ & $2.42^{\mathrm{d}}$ & $2.08^{d}$ & $1.77^{\mathrm{d}}$ & $103.21^{\mathrm{d}}$ & $118.26^{\mathrm{d}}$ & $115.90^{\circ}$ \\
\hline & $\mathrm{T}_{1}$ & $19.25^{\mathrm{c}}$ & $18.58^{\mathrm{c}}$ & $15.71^{\mathrm{c}}$ & $0.21^{\mathrm{c}}$ & $0.20^{c}$ & $0.18^{c}$ & $2.50^{c}$ & $2.16^{\mathrm{c}}$ & $1.69^{c}$ & $106.48^{\mathrm{c}}$ & $122.35^{c}$ & $119.34^{\circ}$ \\
\hline & $\mathrm{T}_{2}$ & $23.12^{\mathrm{a}}$ & $21.10^{\mathrm{a}}$ & $18.02^{\mathrm{a}}$ & $0.20^{\mathrm{a}}$ & $0.19^{\mathrm{a}}$ & $0.17^{\mathrm{a}}$ & $2.66^{\mathrm{a}}$ & $2.32^{\mathrm{a}}$ & $1.56^{\mathrm{a}}$ & $95.39^{a}$ & $106.60^{\mathrm{a}}$ & $104.60^{\circ}$ \\
\hline & SM & $22.64^{b}$ & $18.41^{b}$ & $16.41^{\mathrm{b}}$ & $0.23^{b}$ & $0.22^{\mathrm{b}}$ & $0.16^{\mathrm{b}}$ & $2.52^{\mathrm{b}}$ & $2.02^{\mathrm{b}}$ & $1.39^{\mathrm{b}}$ & $105.20^{\mathrm{b}}$ & $122.34^{\mathrm{b}}$ & $118.34^{\mathrm{b}}$ \\
\hline & LSD (5\%) & 0.41 & 0.11 & 0.11 & 0.24 & 0.13 & 0.13 & 0.36 & 0.21 & 0.21 & 0.08 & 0.45 & 0.45 \\
\hline & ANOVA & - & - & - & - & - & - & - & - & - & - & - & - \\
\hline & $\mathrm{T}$ & $71.68^{*}$ & $47.27^{*}$ & $15.18 *$ & $12.96^{*}$ & $25.13^{*}$ & $25.24 *$ & $54.13^{*}$ & $30.23^{*}$ & $21.71^{*}$ & $19.18 *$ & $106.20 *$ & $42.24 *$ \\
\hline & Y & 0.44 & 28.84 & 0.39 & 6.37 & 2.25 & 4.34 & 18.41 & 4.10 & 4.41 & 10.54 & 132.42 & 7.52 \\
\hline & $\mathrm{T} \times \mathrm{Y}$ & 0.74 & 2.24 & 0.74 & 0.06 & 0.76 & 0.31 & 0.90 & 3.30 & 0.29 & 0.23 & 0.27 & 0.38 \\
\hline \multirow[t]{9}{*}{2019} & $\mathrm{~T}_{0}$ & $19.74^{\mathrm{d}}$ & $18.67^{\mathrm{d}}$ & $15.66^{\mathrm{d}}$ & $0.22^{\mathrm{d}}$ & $0.22^{\mathrm{d}}$ & $0.20^{\mathrm{d}}$ & $2.70^{\mathrm{d}}$ & $2.36^{\mathrm{d}}$ & $1.95^{\mathrm{d}}$ & $117.64^{\mathrm{d}}$ & $132.78^{\mathrm{d}}$ & $127.73^{\circ}$ \\
\hline & $\mathrm{T}_{1}$ & $20.58^{c}$ & $19.24^{c}$ & $16.12^{\mathrm{c}}$ & $0.21^{\mathrm{c}}$ & $0.21^{\mathrm{c}}$ & $0.19^{c}$ & $2.80^{c}$ & $2.46^{\mathrm{c}}$ & $1.88^{\mathrm{c}}$ & $112.94^{c}$ & $127.41^{\mathrm{c}}$ & $124.82^{\circ}$ \\
\hline & $\mathrm{T}_{2}$ & $24.51^{\mathrm{a}}$ & $23.45^{\mathrm{a}}$ & $19.45^{\mathrm{a}}$ & $0.22^{\mathrm{a}}$ & $0.22^{\mathrm{a}}$ & $0.20^{\mathrm{a}}$ & $2.93^{\mathrm{a}}$ & $2.59^{\mathrm{a}}$ & $1.79^{a}$ & $104.04^{\mathrm{a}}$ & $120.15^{\mathrm{a}}$ & $119.18^{a}$ \\
\hline & SM & $22.89^{b}$ & $22.64^{\mathrm{b}}$ & $17.64^{b}$ & $0.24^{\mathrm{b}}$ & $0.23^{b}$ & $0.21^{\mathrm{b}}$ & $2.72^{\mathrm{b}}$ & $2.34^{\mathrm{b}}$ & $1.59^{\mathrm{b}}$ & $114.05^{b}$ & $128.06^{\mathrm{b}}$ & $122.06^{\mathrm{b}}$ \\
\hline & LSD (5\%) & 0.36 & 0.19 & 0.19 & 0.36 & 0.22 & 0.22 & 0.16 & 0.14 & 0.14 & 0.05 & 0.52 & 0.52 \\
\hline & ANOVA & - & - & - & - & - & - & - & - & - & - & - & - \\
\hline & $\mathrm{T}$ & $10.31^{*}$ & $21.65^{*}$ & 13.88* & $36.49 *$ & $35.45^{*}$ & $3.65^{*}$ & $72.82 *$ & $22.26^{*}$ & $24.21 *$ & $32.34^{*}$ & $181.23^{*}$ & $25.41^{*}$ \\
\hline & Y & 35.0 & 1.94 & 212.10 & 1.82 & 0.47 & 0.48 & 8.62 & 1.28 & 3.46 & 6.37 & 121.72 & 8.15 \\
\hline & $\mathrm{T} \times \mathrm{Y}$ & 0.82 & 0.81 & 0.54 & 0.42 & 0.36 & 0.43 & 0.92 & 0.47 & 1.94 & 0.28 & 0.74 & 0.37 \\
\hline
\end{tabular}

$\mathrm{T}_{0}$ (no potassium), $\mathrm{T}_{1}$ (maize 40 and soybean $30 \mathrm{~K}_{2} \mathrm{O} \mathrm{kg} \mathrm{ha-1}$ ) and $\mathrm{T}_{2}$ (maize 80 and soybean $60 \mathrm{~K}_{2} \mathrm{O} \mathrm{kg} \mathrm{ha}{ }^{-1}$ ) represent the treatment, respectively, in maize-soybean intercropping. The SM refers to the sole-maize cropping. Means averaged over three replicates \pm standard error. ${ }^{\mathrm{a}-\mathrm{d}} \mathrm{Means}$ that do not share the same letters in the columns differ significantly at $\mathrm{P} \leq 0.05$ 
However, different $\mathrm{K}$ application to maize plants significantly improved the partitioning of biomass into reproductive organs relative to $\mathrm{K}_{2} \mathrm{O}$ treatments (Figure 5). On average, cob and grain weight was increased by $8 \%$ and $10 \%$ in $\mathrm{T}_{2}$ relative to $\mathrm{T}_{0}$ treatment, respectively.

\section{Effects of potassium concentration on seed yield and yield attributes}

Maize yield components, kernel number plant $^{-1}$ (KNP) and kernel weight plant $^{-1}(\mathrm{KWP})(\mathrm{g})$ in response to different $\mathrm{K}$ treatments were significant $(\mathrm{P}<0.05)$ in SM and MSI (Table 4). In MSI, the different $\mathrm{K}$ treatments had a significant $(\mathrm{P}>0.05)$ effect on KNP of maize, and the maximum KNP, mean (439.5 plant $^{-1}$ ), was recorded in $\mathrm{T}_{2}$, while minimum $\mathrm{KNP}\left(400.5\right.$ plant $\left.^{-1}\right)$ was observed in $\mathrm{T}_{0}$ treatment. Meanwhile, KWP was significantly $(\mathrm{P}<0.05$, LSD) decreased by $\mathrm{K}$ in $\mathrm{T}_{0}$ and $\mathrm{T}_{1}$ treatments, whereas adequate $\mathrm{K}_{2} \mathrm{O}$ application $\left(\mathrm{T}_{2}\right)$ produced significantly weightier seeds (106.2 g) as compared to other treatments for both years. Seed yield was found non-significant $(\mathrm{P}>0.05)$ and significant in 2018 and 2019, respectively. Comparing with $\mathrm{T}_{0}$, the $\mathrm{T}_{2}$ increased the maize KNP, KWP, seed index by $10 \%, 23 \%$, and $17 \%$, respectively, in MSI.
In SM, the mean highest numbers of KNP 432.7, KWP 105.3, seed index 286.7 was recorded in $\mathrm{T}_{2}$, followed by $\mathrm{T}_{1} 425.4 \mathrm{KNP}$, 107.2 KWP, 79.81 seed index 282.5, while $\mathrm{T}_{0}$ produced minimum KNP 419, KWP 102.1, seed index 274.9, respectively, under SM (Table 4). These results revealed that the $\mathrm{T}_{2}$ treatment in MSI and SM mainly affected KNP, KWP, and seed index during the year of growing seasons.

\section{Regression analysis}

A regression analysis was performed to evaluate the correlation between various measured parameters of maize plants grown in MSI and $\mathrm{K}_{2} \mathrm{O}$ treatments. Regression coefficients reveal a positive relationship between physiological parameters measured at $R_{2}$ growth stage (the LAI $\mathrm{R}^{2}: 0.88$, chlorophyll contents $\mathrm{R}^{2}$ : 0.91 , photosynthesis $\mathrm{R}^{2}: 0.81$, TBA $\mathrm{R}^{2}: 0.94$ ) and at $\mathrm{R}_{6}$ (light transmittance $R^{2}: 0.84$ and seed yield $R^{2}: 0.96$ ) and $\mathrm{K}_{2} \mathrm{O}$ treatment (Figure 6). Almost all the morphological parameters of maize increased with the increased $\mathrm{K}_{2} \mathrm{O}$ application. The regression coefficient between all the measured parameters and increasing $\mathrm{K}_{2} \mathrm{O}$ applications for the mean datasets of 2018 and 2019 were all higher than 0.81 $(\mathrm{P}<0.05)$.
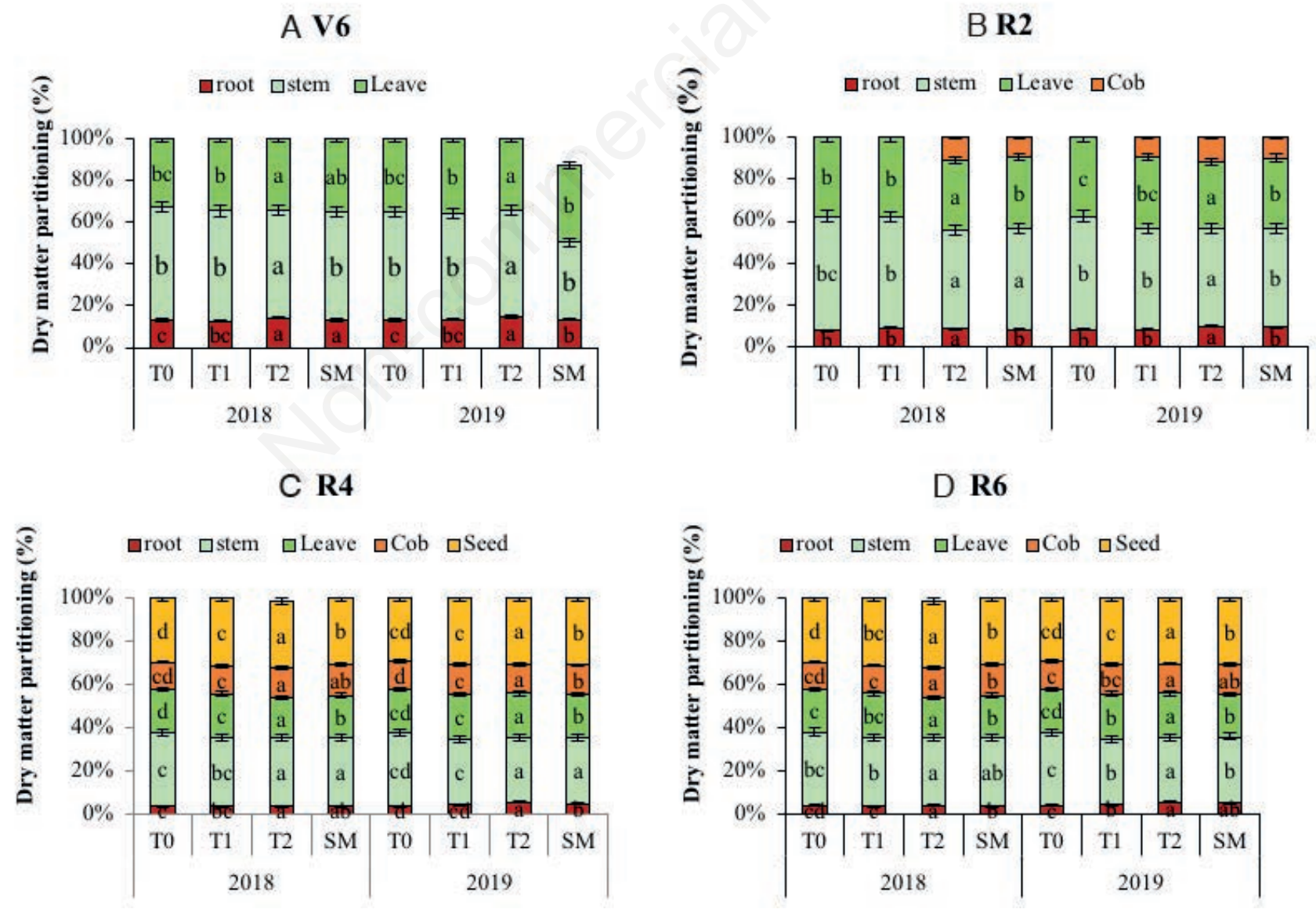

Figure 5. A-D) Effects of potassium on dry matter partitioning of maize at four stages maize six leaves $\left(\mathbf{V}_{6}\right)$, blister $\left(\mathbf{R}_{2}\right)$, dough $\left(\mathbf{R}_{4}\right)$, and physiological maturity $\left(R_{6}\right)$ of phenological development in the strip intercropping system with soybean. Error bars indicate \pm standard errors. 


\section{Discussion}

\section{Potassium and light interception}

Natural light is a significant environmental element in agricultural development (Feng et al., 2019). In farmlands, maize crops mostly experience shade conditions on their middle and lower strata (Liu et al., 2017). The light interception of SM and MSI maize leaves in was enhanced significantly however, light interception was significantly $(\mathrm{P}<0.5)$ higher in MSI than $\mathrm{SM}$ in both years (Figure 2). Spatial light distribution advantage and the edge row advantage are benefits of the narrow-wide-row planting arrangement used in MSI and the complementary role of soybean in MSI improved nutrient availability for maize, which resulted in higher LAI (Figure 3) leading to a higher light interception in intercropped maize (Raza et al., 2019b). Furthermore, we observed treatment $\mathrm{T}_{2}$ significantly improved light interception in our experiment from $18 \%$ in $V_{6}, 27 \%$ in $\mathrm{R}_{2}$ to $31 \%$ in $\mathrm{R}_{4}$ and $35 \%$ at $\mathrm{R}_{6}$. Our results are consistent with (Pettigrew and Meredith $\mathrm{Jr}$, 1997) for cotton and (Jordan-Meille and Pellerin 2004) for maize. The increase in a light interception for $\mathrm{K}$ treated plants might be a result of an increase in LAI (Jordan-Meille and Pellerin, 2004; Pettigrew and Meredith Jr, 1997). K treatments increased LAI in MSI and SM (Figure 3 ) as compared to $\mathrm{T}_{0}$. A consequence of physiological processes influenced by inadequate $\mathrm{K}$ is a reduction in plant size (Ebelhar and Varsa, 2000), and this is often characterised by a decrease in leaf area (Jordan-Meille and Pellerin, 2004; Pettigrew and Meredith Jr, 1997).

\section{Potassium and photosynthesis characteristics}

Sun-light affects crop growth and production, during the photosynthesis process, plants use light to transform water and $\mathrm{CO}_{2}$ to sugar, and chlorophyll plays a vital role in converting light energy to chemical energy (Yuncong et al., 2007; Fan et al., 2018). Earlier experiments suggest chlorophyll content is significantly influenced by light conditions and reduces during shading conditions ( $\mathrm{Su}$ et al., 2014). Furthermore, throughout our research, optimal $\mathrm{K}_{2} \mathrm{O}\left(\mathrm{T}_{2}\right)$ improved the chlorophyll content of maize leaves in SM and MSI (Table 3). Such improvement may enhance photosynthesis, water accumulation, and regulation, stomatal opening in leaves (Dobermann, 2001; Oosterhuis, 2001). Many studies have also proposed that increasing potassium rates promotes the chlorophyll concentration of crops (Hu et al., 2016; Oosterhuis et al., 2014). Photosynthetic characteristics respond to changes in LAI induced by different $\mathrm{K}$ treatments (Wang et al., 2015). Generally, an increase in LAI leads to an improvement of the photosynthetic rate (Khalid et al., 2019).

Moreover, under MSI, with optimum K application, the LAI is essential for developing a plant structure that maintains a higher photosynthesis rate (Shuting et al., 2000; Zhao et al., 2001). In our study, $\mathrm{T}_{2}$ maize plants in SM and MSI maintained a higher photosynthetic rate (Table 3). The increase in chlorophyll content and the effective distribution of photo-assimilates could be associated with these photosynthesis expressions after optimal $\mathrm{K}$ application when the maize plant was at the reproductive stage. Besides, the lower LAI in $\mathrm{T}_{1}$ and $\mathrm{T}_{0}$ could contribute to the reduced photosynthetic rate. Our findings suggest that photosynthetic characteris-

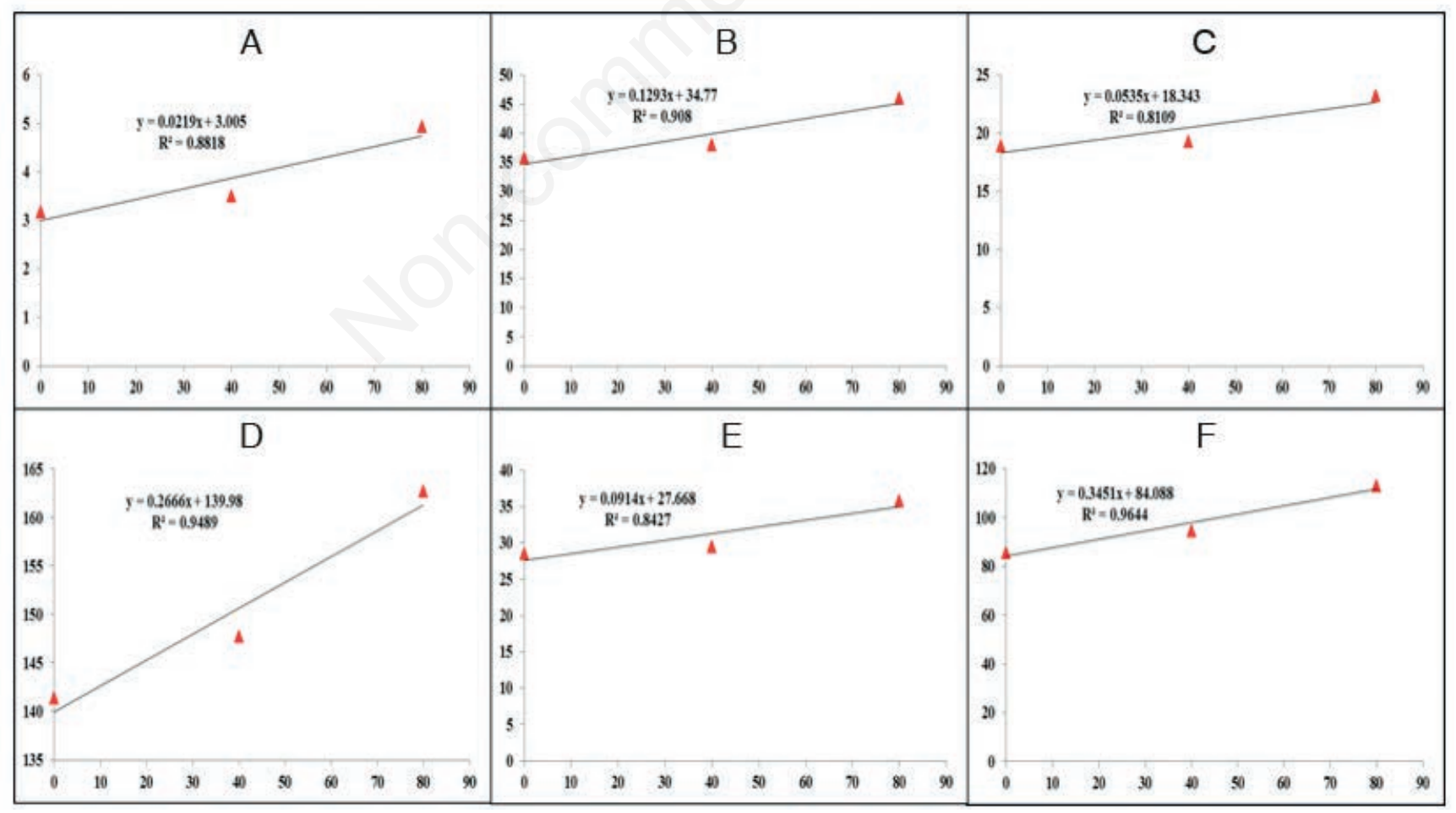

Figure 6. Relationship between leaf area index (A), chlorophyll contents (B), photosynthesis (C), total biomass (D) at $R_{2}$, light transmittance $(E)$, and seed yield $(F)$ at $R_{6}$ respectively, for 2018 and 2019 . Error bars indicate \pm standard errors. 
tics, as affected by $\mathrm{K}$ treatments, are directly linked to changes in LAI, light interception, and chlorophyll content.

\section{Potassium and total biomass accumulation and distri- bution}

Figure 5 presents the data on total biomass accumulation in maize plants under various $\mathrm{K}$ treatments. The photosynthetic rate of maize plants changed with various $\mathrm{K}$ treatments in this study as a result of a combination of factors such as an increase in leaf area and an improved light interception, which could lead to an increase in the total photosynthates produced by maize leaves (Pettigrew, 2008b). Potassium enhances dry matter production in maize (Wiebold and Scharf, 2006) and the improvement in maize biomass yield with the application of $\mathrm{K}$ may also be due to an increase in the rate of assimilation of $\mathrm{CO}_{2}$, improved stomata control and enhanced enzyme activity resulting in the production of more carbohydrates thus increase in biomass yield (Tabatabaii et al., 2011). Earlier studies suggested that the optimal application of $\mathrm{K}$ for wheat and cotton improves TBA, which in effect increases the availability of grain filling for seed production (Gerardeaux et al., 2009; Ma et al., 2013). The growth in leaf area and leaf numbers of maize showed a positive relationship with an increase in dry matter portioning and total dry matter accumulation. Regression analysis also revealed a positive relationship between $\mathrm{K}_{2} \mathrm{O}$ treatments and biomass accumulation (Figure 6). According to (Baque et al., 2006), K applications also increases the portioning of dry matter.

Furthermore, enhanced biomass production of maize plants could be related to the significant nutrients utilisation and remobilisation (Raza et al., 2019c) as the availability of major nutrients improve with $\mathrm{K}_{2} \mathrm{O}$ application in maize crop (Eskandari et al., 2009). Further, we analysed the biomass distribution in seeds of leaves, stems, and cob in maize in response to $\mathrm{K}_{2} \mathrm{O}$ treatments (Figure 5). In all treatments, the biomass distribution pattern was different at $\mathrm{R}_{4}$ and $\mathrm{R}_{6}$, and most of the biomass was translocated to the reproductive part (grains) (Yuhui et al., 2019). Comparable to our findings, researchers have already reported that the optimum application of $\mathrm{K}_{2} \mathrm{O}\left(\mathrm{T}_{2}\right)$ enhanced the translocation of photo-assimilates to economic sections and minimised the distribution of biomass to vegetative parts (Patrick et al., 2001; Pan et al., 2017). Furthermore, the $\mathrm{K}$ treatment increased the partitioning of biomass in stem and ear bracts (DU et al., 2007), which enhanced the crop yields (Table 4), probably due to a reduction in stalk lodging (Pettigrew, 2008b).

\section{Potassium, seed yield and yield components}

Further, we investigated in this study, the influences of $\mathrm{K}_{2} \mathrm{O}$ treatments on seed yield and yield attributes. Studies demonstrated that the maximum crop yield was achieved in the optimal $\mathrm{K}_{2} \mathrm{O}$ maize application $\left(\mathrm{T}_{2}\right)$, with a 17 percent increase in 2018 , and 15 percent in 2019, in comparison to $\mathrm{T}_{0}$ (control treatment) as in Table 4. Additionally, significant differences $(\mathrm{P}<0.05)$ were also noticed for seed number plant ${ }^{-1}$ and seed weight $(\mathrm{g})$ in response to $\mathrm{K}_{2} \mathrm{O}$ application treatments, while the higher seed weight and seed number were recorded under $\mathrm{T}_{2}$ treatment. This increase in the number of seeds for the maize crop could be attributed to the high translocation of biomass to seed (Table 4). Likewise, improved seed weight (Table 4) under $\mathrm{T}_{2}$ in SM and MSI might be due to higher LAI (Figure 3) (Chen et al., 2016) and photosynthetic rate (Table 3) at physiological maturity. However, reduced LAI, photosynthetic capacity, and biomass accumulation of maize plants in $\mathrm{T}_{0}$ and $\mathrm{T}_{1}$ decreased the seed number and seed weight (Zhan et al., 2016). Under optimum $\mathrm{K}$ application increased the $\mathrm{HI}$ of maize, and this might be attributed to the decreased dry matter of vegetative parts as compared to the dry matter of reproductive parts (Amanullah et al., 2015).

\section{Conclusions}

In conclusion, this field study planned to examine the influences of different $\mathrm{K}_{2} \mathrm{O}$ treatments on light interception, and photo-

Table 4. Effect of $\mathrm{K}_{2} \mathrm{O}$ application on seed yield and yield-related traits of maize-soybean intercropping and sole maize cropping during cropping seasons of 2018 and 2019.

\begin{tabular}{|c|c|c|c|c|c|c|c|c|c|}
\hline \multirow{3}{*}{$\begin{array}{l}\text { Years } \\
\text { (Y) }\end{array}$} & \multirow{3}{*}{$\begin{array}{l}\text { Treatments } \\
\text { (T) }\end{array}$} & \multicolumn{8}{|c|}{ Yield components of maize } \\
\hline & & & Intercrop & -maize & & & Sole crop-I & aize & \\
\hline & & $\begin{array}{l}\text { Kernels } \\
\text { plant }^{-1}\end{array}$ & $\begin{array}{l}\text { Kernels weight } \\
\text { plant }^{-1}(\mathrm{~g})\end{array}$ & Seed index & 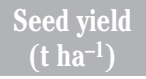 & $\begin{array}{l}\text { Kernels } \\
\text { plant }^{-1}\end{array}$ & $\begin{array}{l}\text { Kernels weight } \\
\text { plant }^{-1}(\mathrm{~g})\end{array}$ & Seed index & $\begin{array}{c}\text { Seed yield } \\
\left(t h a^{-1}\right)\end{array}$ \\
\hline \multirow[t]{8}{*}{2018} & $\mathrm{~T}_{0}$ & $394 \pm 0.02^{c}$ & $82.88 \pm 0.17^{c}$ & $246.05 \pm 0.26^{\mathrm{c}}$ & $4.973 \pm 0.09 \mathrm{c}$ & $409.00 \pm 0.08^{c}$ & $101.77 \pm 0.05^{\mathrm{c}}$ & $261.29 \pm 0.05^{\mathrm{c}}$ & $6.106 \pm 0.04^{\mathrm{c}}$ \\
\hline & $\mathrm{T}_{1}$ & $402 \pm 0.01^{b}$ & $85.82 \pm 0.07^{\mathrm{b}}$ & $253.57 \pm 0.17^{\mathrm{b}}$ & $5.149 \pm 0.03^{b}$ & $415.32 \pm 0.35^{b}$ & $102.20 \pm 0.61^{b}$ & $274.80 \pm 0.45^{b}$ & $6.189 \pm 0.47^{b}$ \\
\hline & $\mathrm{T}_{2}$ & $432 \pm 0.06^{\mathrm{a}}$ & $104.87 \pm 0.20^{\mathrm{a}}$ & $288.48 \pm 0.22^{\mathrm{a}}$ & $6.292 \pm 0.02^{\mathrm{a}}$ & $424.08 \pm 0.58^{\mathrm{a}}$ & $104.62 \pm 0.85^{\mathrm{a}}$ & $281.36 \pm 0.96^{\mathrm{a}}$ & $6.205 \pm 0.21^{\mathrm{a}}$ \\
\hline & LSD (5\%) & 0.15 & 0.52 & 0.18 & 0.15 & 0.78 & 0.34 & 1.68 & 4.65 \\
\hline & ANOVA & - & - & - & - & - & - & - & - \\
\hline & $\mathrm{T}$ & $3.29 *$ & $4.27^{*}$ & $6.24^{*}$ & $10.02 *$ & $0.91^{*}$ & $3.05^{*}$ & $5.13^{*}$ & $9.20^{*}$ \\
\hline & Y & 2.78 & 0.92 & 2.04 & 4.73 & 2.18 & 11.72 & 3.67 & 38.65 \\
\hline & $\mathrm{T} \times \mathrm{Y}$ & 4.73 & 2.42 & 0.49 & 1.15 & 0.29 & 0.06 & 0.79 & 0.55 \\
\hline \multirow[t]{8}{*}{2019} & $\mathrm{~T}_{0}$ & $407 \pm 0.10^{c}$ & $89.75 \pm 0.20^{c}$ & $252.32 \pm 0.46^{\mathrm{c}}$ & $5.385 \pm 0.05^{c}$ & $429 \pm 0.08^{c}$ & $102.33 \pm 0.48^{c}$ & $288.48 \pm 0.34 \mathrm{c}$ & $6.200 \pm 0.04^{c}$ \\
\hline & $\mathrm{T}_{1}$ & $419 \pm 0.06^{b}$ & $91.62 \pm 0.01^{\mathrm{b}}$ & $269.07 \pm 0.11^{b}$ & $5.49 \pm 0.30^{\mathrm{b}}$ & $435.47 \pm 0.23^{b}$ & $104.14 \pm 0.65^{b}$ & $290.13 \pm 0.78^{b}$ & $6.285 \pm 0.52^{b}$ \\
\hline & $\mathrm{T}_{2}$ & $447 \pm 0.59^{a}$ & $107.42 \pm 0.27^{a}$ & $295.56 \pm 0.20^{\mathrm{a}}$ & $6.445 \pm 0.06^{\mathrm{a}}$ & $441.41 \pm 0.58^{\mathrm{a}}$ & $105.98 \pm 0.17^{\mathrm{a}}$ & $292.03 \pm 0.8^{a}$ & $6.340 \pm 0.98^{a}$ \\
\hline & LSD (5\%) & 0.98 & 0.55 & 0.66 & 0.19 & 0.68 & 0.14 & 2.15 & 2.89 \\
\hline & ANOVA & - & - & - & - & - & - & - & - \\
\hline & $\mathrm{T}$ & $4.72 *$ & $0.67^{*}$ & $10.13^{*}$ & $7.62^{*}$ & $1.16^{*}$ & $20.21 *$ & $18.34^{*}$ & $2.47^{*}$ \\
\hline & Y & 11.26 & 21.94 & 7.69 & $1.93^{*}$ & 6.92 & 0.87 & $9.04^{*}$ & 19.23 \\
\hline & $\mathrm{T} \times \mathrm{Y}$ & 0.64 & 0.14 & 0.38 & 0.50 & 0.31 & 0.29 & 3.23 & 0.09 \\
\hline
\end{tabular}

$\mathrm{T}_{0}$ (no potassium), $\mathrm{T}_{1}$ (maize 40 and soybean $30 \mathrm{~K}_{2} \mathrm{O} \mathrm{kg} \mathrm{ha-1}$ ) and $\mathrm{T}_{2}$ (maize 80 and soybean $60 \mathrm{~K}_{2} \mathrm{O} \mathrm{kg} \mathrm{ha}^{-1}$ ) represent the treatment, respectively, in maize-soybean intercropping. Means averaged over three replicates \pm standard error. Means that do not share the same letters in the columns differ significantly at $\mathrm{P} \leq 0.05$. 
synthetic characteristics, biomass accumulation, and its distribution in various plant parts and grain yield under MSI and SM. In this experiment, we applied different $\mathrm{K}_{2} \mathrm{O}$ treatments and observed that the under optimum $\mathrm{K}_{2} \mathrm{O}$ application to maize under MSI and SM led to an increase in leaf area index and photosynthetic rates, which increased grain yields as a result of enhanced the translocation of photo-assimilates to economic parts of maize plants. Besides, this increase in grain yield of the maize crop is attributed to an enhanced biomass accumulation during the seed filling stage, which increased the seed number and seed weight. The achievement and maintenance of maximum maize yields will depend on an appropriately managed $\mathrm{K}$ fertilisation program. Based on our findings, we recommend optimum $\mathrm{K}_{2} \mathrm{O}$ application (80:60 $\mathrm{kg} \mathrm{ha}^{-1}$ ) for areas with similar soil and climatic conditions for a higher light interception, photosynthetic activity, and grain yield under MSI and SM. Furthermore, our results provide a new insight to small growers to grow maize-soybean under optimum $\mathrm{K}_{2} \mathrm{O}$ application. Finally, we suggest small growers apply optimum $\mathrm{K}_{2} \mathrm{O}(80: 60 \mathrm{~kg}$ $\mathrm{ha}^{-1}$ ) under the MSI planting system for better plant growth, photosynthetic performance, and profitable maize yields.

\section{References}

Ahmed A, Aftab S, Hussain S, Nazir Cheema H, Liu W, Yang F, Yang W, 2020. Nutrient accumulation and distribution assessment in response to potassium application under maize-soybean intercropping system. Agronomy 10:725.

Amanullah A, Iqbal A, Iqbal M, 2015. Impact of potassium rates and their application time on dry matter partitioning, biomass and harvest index of maize (Zea mays) with and without cattle dung application. Emirates J. Food Agric.: 447-53.

Amanullah I, 2016. Residual phosphorus and zinc influence wheat productivity under rice-wheat cropping system. Springerplus 5:255.

Baque MA, Karim MA, Hamid A, Tetsushi H, 2006. Effects of fertilizer potassium on growth, yield and nutrient uptake of wheat (Triticum aestivum) under water stress conditions. South Pacific. Stud. 27:25-35.

Bengtsson H, Öborn I, Jonsson S, Nilsson I, Andersson A, 2003. Field balances of some mineral nutrients and trace elements in organic and conventional dairy farming - a case study at Öjebyn, Sweden. Eur. J. Agron. 20:101-16.

Chen Q, Mu X, Chen F, Yuan L, Mi G, 2016. Dynamic change of mineral nutrient content in different plant organs during the grain filling stage in maize grown under contrasting nitrogen supply. Eur. J. Agron. 80:137-53.

Clergue B, Amiaud B, Pervanchon F, Lasserre-Joulin F, Plantureux S, 2009. Biodiversity: function and assessment in agricultural areas: a review. In: Sustainable Agriculture. Springer, pp 309-27.

Cong R, Li H, Zhang Z, Ren T, Li X, Lu J, 2016. Evaluate regional potassium fertilization strategy of winter oilseed rape under intensive cropping systems: Large-scale field experiment analysis. F. Crop. Res. 193:34-42.

Dan Y, Shi-Hua QI, Zhang J-Q, Tan L-Z, Zhang J-P, Zhang Y, Feng X, Xin-Li X, Ying H, Wei C, 2012. Residues of organochlorine pesticides (OCPs) in agricultural soils of Zhangzhou City, China. Pedosphere 22:178-89.

Darilek JL, Huang B, Wang Z, Qi Y, Zhao Y, Sun W, Gu Z, Shi X, 2009. Changes in soil fertility parameters and the environmental effects in a rapidly developing region of China. Agric. Ecosyst. Environ. 129:286-92.
Dobermann AR, 2001. Crop potassium nutrition-implications for fertilizer recommendations. Agronomy \& Horticulture Faculty Publications. 17:357 in Proc. $31^{\text {st }}$ North Central Ext. Indus. Soil Fert. Conf., Des Moines, Iowa state, USA.

Dong H, Kong X, Li W, Tang W, Zhang D, 2010. Effects of plant density and nitrogen and potassium fertilization on cotton yield and uptake of major nutrients in two fields with varying fertility. F. Crop. Res. 119:106-13.

Du X, Zhang L, Li H, Yang F, Bian X, 2007. Effects of potassium application on nutrient absorption dynamics, biomass and quality formation of forage maize. Plant Nutr. Fertil. Sci. 13:393-7.

Duchene O, Vian J-F, Celette F, 2017. Intercropping with legume for agroecological cropping systems: complementarity and facilitation processes and the importance of soil microorganisms. A review. Agric. Ecosyst. Environ. 240:148-61.

Ebelhar SA, Varsa EC, 2000. Applications in sustainable production: Tillage and potassium placement effects on potassium utilization by corn and soybean. Commun. Soil Sci. Plant Anal. 31:2367-77.

Epstein E, Bloom AJ, 2005. Mineral nutrition of plants: principles and perspectives. 2nd ed. Sinauer Assoc. Inc., Sunderland, UK.

Eskandari H, Ghanbari-Bonjar A, Galavi M, Salari M, 2009. Forage quality of cow pea (Vigna sinensis) intercropped with corn (Zea mays) as affected by nutrient uptake and light interception. Not. Bot. Horti Agrobot. Cluj-Napoca 37:171-4.

Fan Y, Chen J, Cheng Y, Raza MA, Wu X, Wang Z, Liu Q, Wang R, Wang X, Yong T, 2018. Effect of shading and light recovery on the growth, leaf structure, and photosynthetic performance of soybean in a maize-soybean relay-strip intercropping system. PLoS One 13:e198159.

Feng L, Raza MA, Chen Y, Khalid MH Bin, Meraj TA, Ahsan F, Fan Y, Du J, Wu X, Song C, 2019. Narrow-wide row planting pattern improves the light environment and seed yields of intercrop species in relay intercropping system. PLoS One 14:e0212885.

Gerardeaux E, Saur E, Constantin J, Porté A, Jordan-Meille L, 2009. Effect of carbon assimilation on dry weight production and partitioning during vegetative growth. Plant Soil 324:329-43.

Gliessman SR, 1990. Agroecology: researching the ecological basis for sustainable agriculture. In: Agroecology. Springer, pp $3-10$.

Grote U, Craswell E, Vlek P, 2005. Nutrient flows in international trade: Ecology and policy issues. Environ. Sci. Policy 8:439-51.

He C, Ouyang Z, Tian Z, Schaffer HD, 2012. Yield and potassium balance in a wheat-maize cropping system of the North China Plain. Agron. J. 104:1016-22.

He P, Yang L, Xu X, Zhao S, Chen F, Li S, Tu S, Jin J, Johnston AM, 2015. Temporal and spatial variation of soil available potassium in China (1990-2012). F. Crop. Res. 173:49-56.

Hedlund A, Witter E, An BX, 2003. Assessment of N, P and K management by nutrient balances and flows on peri-urban smallholder farms in southern Vietnam. Eur. J. Agron. 20:71-87.

Homer CD, Pratt PF, 1961. Methods of analysis for soils, plants and waters. University of California. Agr. Sci. Publ. Berkeley, USA.

Hu W, Zhao W, Yang J, Oosterhuis DM, Loka DA, Zhou Z, 2016. Relationship between potassium fertilization and nitrogen metabolism in the leaf subtending the cotton (Gossypium hirsutum L.) boll during the boll development stage. Plant Physiol. Biochem. 101:113-23.

Huoyan W, Cheng W, Ting L, Jianmin Z, Xiaoqin C, 2016. Can nonexchangeable potassium be differentiated from structural potassium in soils? Pedosphere 26:206-15. 
Jackson ML, 1973. Soil chemical analysis. Prentice hall of india Pvt. Ltd., New Delhi, India, pp 478.

Jenkinson DS, 1968. Chemical tests for potentially available nitrogen in soil. J. Sci. Food Agric. 19:160-8.

Jordan-Meille L, Pellerin S, 2004. Leaf area establishment of a maize (Zea mays L.) field crop under potassium deficiency. Plant Soil 265:75-92.

Khalid M, Raza M, Yu H, Sun F, Zhang Y, Lu F, Si L, Iqbal N, Khan I, Fu F, 2019. Effect of shade treatments on morphology, photosynthetic and chlorophyll fluorescence characteristics of soybeans (Glycine max L. Merr.). Appl. Ecol. Environ. Res. 17:2551-69.

Li S, Duan Y, Guo T, Zhang P, He P, Johnston A, Shcherbakov A, 2015. Potassium management in potato production in Northwest region of China. F. Crop. Res. 174:48-54.

Liu T, Huang R, Cai T, Han Q, Dong S, 2017. Optimum leaf removal increases nitrogen accumulation in kernels of maize grown at high density. Sci. Rep. 7:1-10.

Liu W, Deng Y, Hussain S, Zou J, Yuan J, Luo L, Yang C, Yuan X, Yang W, 2016. Relationship between cellulose accumulation and lodging resistance in the stem of relay intercropped soybean [Glycine max (L.) Merr.]. F. Crop. Res. 196:261-7.

Liu X, Rahman T, Song C, Yang F, Su B, Cui L, Bu W, Yang W, 2018. Relationships among light distribution, radiation use efficiency and land equivalent ratio in maize-soybean strip intercropping. F. Crop. Res. 224:91-101.

Ma Q, Scanlan C, Bell R, Brennan R, 2013. The dynamics of potassium uptake and use, leaf gas exchange and root growth throughout plant phenological development and its effects on seed yield in wheat (Triticum aestivum) on a low-K sandy soil. Plant Soil 373:373-84.

Moonen A-C, Barberi P, 2008. Functional biodiversity: an agroecosystem approach. Agric. Ecosyst. Environ. 127:7-21.

Niu J, Zhang W, Chen X, Li C, Zhang F, Jiang L, Liu Z, Xiao K, Assaraf M, Imas P, 2011. Potassium fertilization on maize under different production practices in the North China Plain. Agron. J. 103:822-9.

Niu J, Zhang W, Ru S, Chen X, Xiao K, Zhang X, Assaraf M, Imas P, Magen H, Zhang F, 2013. Effects of potassium fertilization on winter wheat under different production practices in the North China Plain. F. Crop. Res. 140:69-76.

Olsen SR, Sommers LE, 1982. Phosphorus. p. 403-430. AL Page et al.(ed.) Methods of soil analysis. Part 2. Agron. Monogr. 9. ASA and SSSA, Madison, WI.

Olsen SR, 1954. Estimation of available phosphorus in soils by extraction with sodium bicarbonate. US Department of Agriculture. Cir. 939.

Oosterhuis D, 2001. Physiology and nutrition of high yielding cotton in the USA. Informações Agronômicas 95:18-24.

Oosterhuis DM, Loka DA, Kawakami EM, Pettigrew WT, 2014. The physiology of potassium in crop production. In: Advances in agronomy. Elsevier, pp 203-33.

Page AL, Miller RH, Keeney DR, 1982. Methods of soil analysis. Part 2. American Society of Agronomy. Soil Sci. Soc. Am. Madison, WI, USA.

Pan Y, Lu Z, Lu J, Li X, Cong R, Ren T, 2017. Effects of low sink demand on leaf photosynthesis under potassium deficiency. Plant Physiol. Biochem. 113:110-21.

Patrick JW, Zhang W, Tyerman SD, Offler CE, Walker NA, 2001. Role of membrane transport in phloem translocation of assimilates and water. Funct. Plant Biol. 28:697-709.

Pettigrew WT, 2008a. Effects of K on plant metabolism. Physiol. Plant 133:670-81.
Pettigrew WT, 2008b. Potassium influences on yield and quality production for maize, wheat, soybean and cotton. Physiol. Plant. 133:670-81.

Pettigrew WT, Meredith Jr WR, 1997. Dry matter production, nutrient uptake, and growth of cotton as affected by potassium fertilization. J. Plant Nutr. 20:531-48.

Pietsch D, Mabit L, 2012. Terrace soils in the Yemen Highlands: using physical, chemical and radiometric data to assess their suitability for agriculture and their vulnerability to degradation. Geoderma 185:48-60.

Pretty J, 2008. Agricultural sustainability: concepts, principles and evidence. Philos. Trans. R. Soc. B Biol. Sci. 363:447-65.

Rahman T, Liu X, Hussain S, Ahmed S, Chen G, Yang F, Chen L, Du J, Liu W, Yang W, 2017. Water use efficiency and evapotranspiration in maize-soybean relay strip intercrop systems as affected by planting geometries. PLoS One 12:e0178332.

Raza MA, Feng LY, Khalid MHB, Iqbal N, Meraj TA, Hassan MJ, Ahmed S, Chen YK, Feng Y, Wenyu Y, 2019a. Optimum leaf excision increases the biomass accumulation and seed yield of maize plants under different planting patterns. Ann. Appl. Biol. 175:54-68.

Raza MA, Feng LY, van der Werf W, Cai GR, Khalid MH Bin, Iqbal N, Hassan MJ, Meraj TA, Naeem M, Khan I, 2019b. Narrow-wide-row planting pattern increases the radiation use efficiency and seed yield of intercrop species in relay-intercropping system. Food Energy Secur. 8:e170.

Raza MA, Khalid MH Bin, Zhang X, Feng LY, Khan I, Hassan MJ, Ahmed M, Ansar M, Chen YK, Fan YF, 2019c. Effect of planting patterns on yield, nutrient accumulation and distribution in maize and soybean under relay intercropping systems. Sci. Rep. 9:1-14.

Römheld V, Kirkby EA, 2010. Research on potassium in agriculture: needs and prospects. Plant Soil 335:155-80.

Shuting D, Kongjun W, Changhao H, 2000. Development of canopy apparent photosynthesis among maize varieties from different eras. Zuo Wu Xue Bao 26:200-4.

Su BY, Song YX, Song C, Cui L, Yong TW, Yang WY, 2014. Growth and photosynthetic responses of soybean seedlings to maize shading in relay intercropping system in Southwest China. Photosynthetica 52:332-40.

Tabatabaii ES, Yarnia M, Khorshidi MB, Farajzadeh E, 2011. Effect of potassium fertilizer on corn yield (Jeta cv.) under drought stress condition. Am.-Euras. J. Agric. Environ. Sci 10:257-63.

Wang H-J, Huang B, Shi X-Z, Darilek JL, Yu D-S, Sun W-X, Zhao Y-C, Chang Q, Öborn I, 2008. Major nutrient balances in small-scale vegetable farming systems in peri-urban areas in China. Nutr. Cycl. Agroecosyst. 81:203-18.

Wang X, Zhao X, Jiang C, Li C, Cong S, Wu D, Chen Y, Yu H, Wang C, 2015. Effects of potassium deficiency on photosynthesis and photoprotection mechanisms in soybean (Glycine $\max ($ L.) Merr.). J. Integr. Agric. 14:856-63.

Wezel A, Casagrande M, Celette F, Vian J-F, Ferrer A, Peigné J, 2014. Agroecological practices for sustainable agriculture. A review. Agron. Sustain. Dev. 34:1-20.

Wiebold B, Scharf P, 2006. Potassium deficiency symptoms in drought stressed crops, plant stress resistance and the impact of potassium application south china. Agron. J 98:1354-9.

Wortmann CS, Kaizzi CK, 1998. Nutrient balances and expected effects of alternative practices in farming systems of Uganda. Agric. Ecosyst. Environ. 71:115-29.

Wu L, Cui Z, Chen X, Zhao R, Si D, Sun Y, Yue S, 2014. Highyield maize production in relation to potassium uptake require- 
ments in China. Agron. J. 106:1153-8.

Wu L, Ma W, Zhang C, Wu L, Zhang W, Jiang R, Zhang F, Cui Z, Chen X, 2013. Current potassium-management status and grain-yield response of Chinese maize to potassium application. J. Plant Nutr. Soil Sci. 176:441-9.

Xu X, He P, Pampolino MF, Chuan L, Johnston AM, Qiu S, Zhao S, Zhou W, 2013. Nutrient requirements for maize in China based on QUEFTS analysis. F. Crop. Res. 150:115-25.

Yang F, Huang S, Gao R, Liu W, Yong T, Wang X, Wu X, Yang W, 2014. Growth of soybean seedlings in relay strip intercropping systems in relation to light quantity and red: far-red ratio. F. Crop. Res. 155:245-53.

Yang F, Liao D, Wu X, Gao R, Fan Y, Raza MA, Wang X, Yong T, Liu W, Liu J, 2017. Effect of aboveground and belowground interactions on the intercrop yields in maize-soybean relay intercropping systems. F. Crop. Res. 203:16-23.

Yuhui G, Guojun C, Lichun W, Shuhua W, 2019. Potassium accumulation, partitioning, and remobilization in high-yield spring maize in Northeast China. J. Plant Nutr. 42:1366-77.

Yuncong Y, Shaohui W, Yun K, 2007. Characteristics of photosynthesis machinism in different peach species under low light intensity. Sci. Agric. Sin. 40:855-63.

Zhan A, Zou C, Ye Y, Liu Z, Cui Z, Chen X, 2016. Estimating onfarm wheat yield response to potassium and potassium uptake requirement in China. F. Crop. Res. 191:13-9.

Zhang H-M, Yang X-Y, He X-H, Xu M-G, Huang S-M, Liu H, Wang B-R, 2011. Effect of long-term potassium fertilization on crop yield and potassium efficiency and balance under wheat-maize rotation in China. Pedosphere 21:154-63.

Zhao D, Oosterhuis DM, Bednarz CW, 2001. Influence of potassium deficiency on photosynthesis, chlorophyll content, and chloroplast ultrastructure of cotton plants. Photosynthetica 39:103-9.

Zhen L, Zoebisch MA, Chen G, Feng Z, 2006. Sustainability of farmers' soil fertility management practices: A case study in the North China Plain. J. Environ. Manage. 79:409-19. 